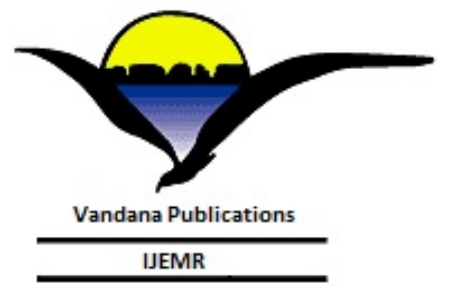

Volume-8, Issue-3, June 2018

International Journal of Engineering and Management Research

Page Number: 42-45

DOI: doi.org/10.31033/ijemr.8.3.4

\title{
A Study on Working Conditions of Unskilled Migrant Labourers in Kerala with Special Reference to Ernakulam District
}

\author{
Saviour F \\ Assistant Professor, Department of Commerce, College of Applied Science, Perissery, Kerala, INDIA
}

Corresponding Author: itssaviour4u@gmail.com

\begin{abstract}
The present paper throws light upon the working environment of the migrant labourers in the state of Kerala. It focusses on the unskilled labourers who work in the unhealthy working conditions of the industrial sector. In spite of their vital role in the economic growth of the state, they are made to work for more than the stipulated time, not even paid for the overtime work. These unskilled labourers and their families face health issues due to the hazardous work and improper medical care. It is a fact that they are employed as temporary workers with neither proper wages nor any other benefits. They are not even added in any of the official records of the city. Even though they face difficulty in the work place, they prefer to stay in the state itself, because of work opportunities. Hence there is a dire need to preserve the interests of these unskilled migrant labourers to protect the social and economic well- being of the state as a whole.
\end{abstract}

Keywords - Labour Migration, Working Environment, Kerala Economy, Labour Migration in Kerala, Unskilled Workers in Kerala

\section{INTRODUCTION}

The migrant workforce play a vital role nationally and across local communities in recent times. The migrant labourers search for more secure environment and better living conditions. It not only transform the lives of the migrants profoundly, but also leads to significant economic and social changes. It is a means to a mutual 'give and take' policy. Today, these migrant labourers have become an integral part of Kerala's economy. When compared to their home state these migrant labourers found Kerala to be a captivating place because of higher wages and better living conditions.

The migrant labourers to Kerala flow from the states like West Bengal, Tripura, Assam, Maharashtra and Tamil Nadu. These labourers are controlled primarily by the labour contractors. In many cases, this further contributes to the exploitation of these migrant labourers. However, over the years, these migrant labourers have become an indispensable part of the commercial sector of Kerala especially in the construction arena and hotel industry. It is a fact that Kerala cannot do without migrant labourers and they dominate in all the arenas of work in every part of Kerala.

This research is conducted to understand the working conditions of migrant unskilled labourers in Kerala state. The researcher also throws light upon the factors that attracted these labourers into the state. The study is an explanatory in nature and data was collected mainly from Kochi, the industrial capital of the State. Data consists of 200 migrant labourers selected at random. These labourers were mainly in construction, hotel industry or engage in local works like cleaning. Data was collected through various interview schedules because majority of them could not read or write in English or in the regional language.

Figure 1

Factors Influencing Unskilled Labour Migration to Kerala

\section{Factors Influencing Unskilled Labour Migration to Kerala}

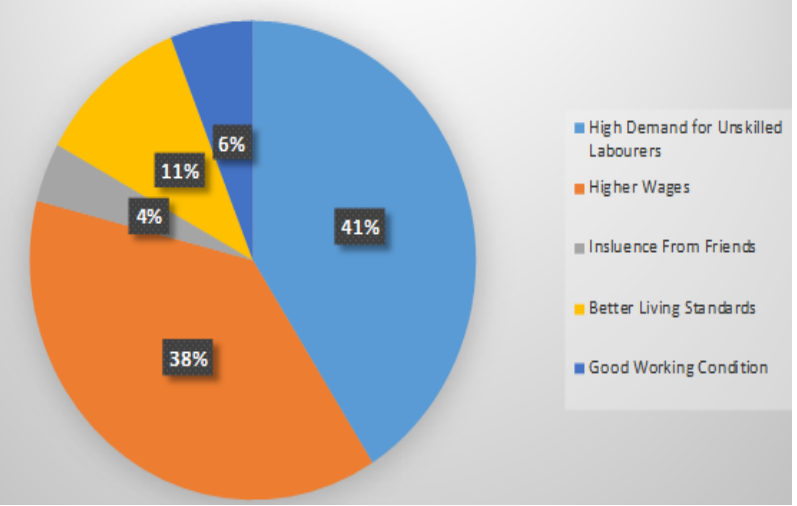

Source: Primary data

Reasons for choosing kerala by Migrant Unskilled Labourers 
As per the above data Main factors which influence unskilled labourers to kerala is the huge demand coming from the state especially from the industrial sector. Higher wages paid to migrant labourers when compared with their homeland is also an influencing factor which attract more unskilled workers to kerala. In construction sector, they are paid between Rs.700/- - Rs. 1000/- a day.

\section{DATA ANALYSIS AND RESULTS}

\section{Profile of the Migrant Labourers}

Table 1

Nature of Work Undertaken

\begin{tabular}{|c|c|c|}
\hline Particulars & $\begin{array}{l}\text { Number of } \\
\text { Respondents }\end{array}$ & Percentage \\
\hline $\begin{array}{l}\text { Migrants from } \\
\text { construction sector }\end{array}$ & 83 & $41.5 \%$ \\
\hline $\begin{array}{l}\text { Migrants from Hotel } \\
\text { industry }\end{array}$ & 64 & $32 \%$ \\
\hline $\begin{array}{l}\text { Migrants going as } \\
\text { local workers }\end{array}$ & 41 & $20.5 \%$ \\
\hline Others & 12 & $6 \%$ \\
\hline Total & 200 & $100 \%$ \\
\hline
\end{tabular}

Source: Primary data

Figure 2

Nature of Work Undertaken

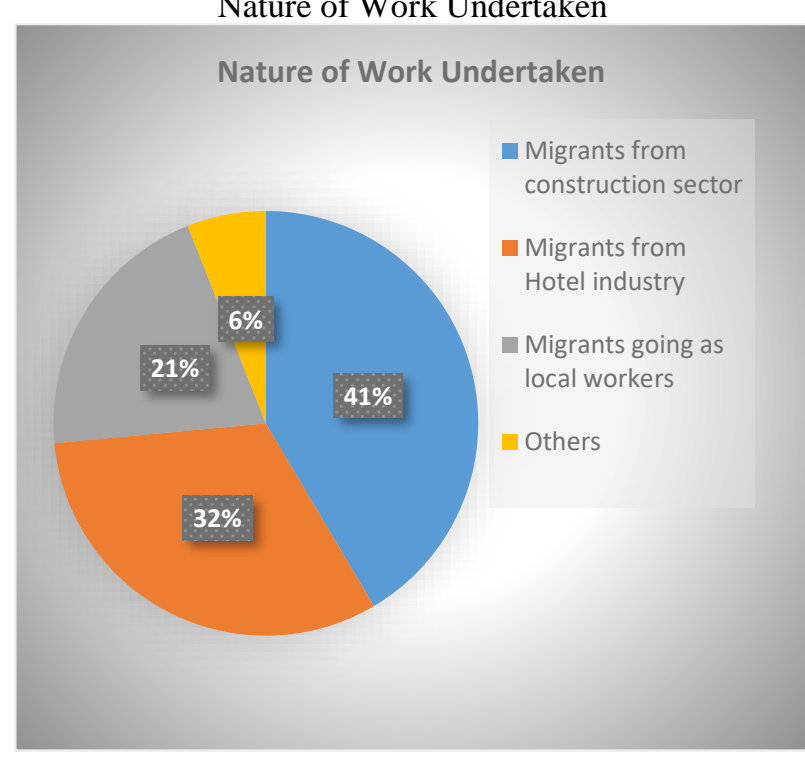

Source: Primary data

Majority of the labourers included in the study were from construction sector and hotel industry. Local workers were mainly engaged in household activities and cleaning activities. Others included those who go for different types of works as per the demand in the society.
Gender wise classification

\begin{tabular}{|l|l|l|}
\hline Particulars & $\begin{array}{l}\text { Number of } \\
\text { Responden } \\
\text { ts }\end{array}$ & Percentage \\
\hline Male & 165 & $82.5 \%$ \\
\hline Female & 35 & $17.5 \%$ \\
\hline Total & $\mathbf{2 0 0}$ & $\mathbf{1 0 0} \%$ \\
\hline
\end{tabular}

Source: Primary data

Figure 3

Gender wise classification

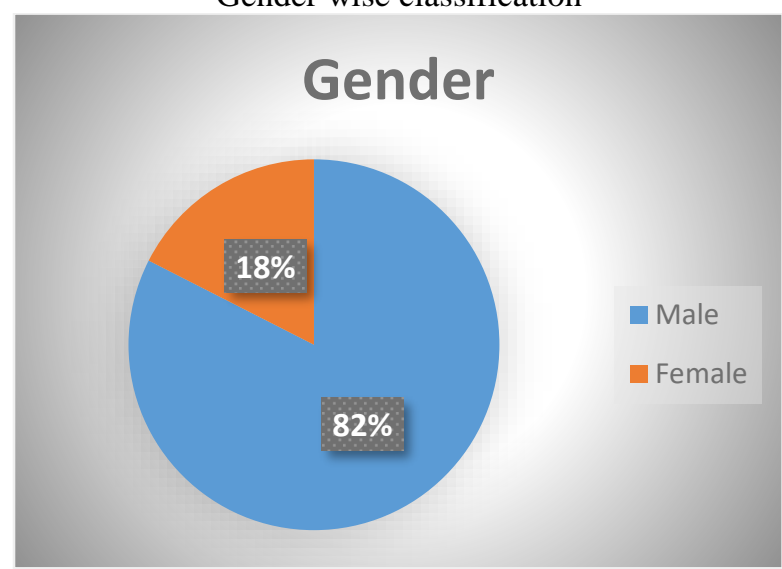

Source: Primary data

Majority of the labourers included in the study were Male workers. Male respondents mainly came from West Bengal and female respondents mainly from Tamil Nadu.

2. Analysis of Working Condition

Table 3

Working Hours

\begin{tabular}{|l|l|l|}
\hline Hours of Work & $\begin{array}{l}\text { Number of } \\
\text { Respondents }\end{array}$ & Percentage \\
\hline $\begin{array}{l}\text { Less than } 8 \\
\text { hours }\end{array}$ & 0 & $0 \%$ \\
\hline 8 hours & 21 & $10.5 \%$ \\
\hline 8-10 hours & 66 & $33 \%$ \\
\hline Above 10 hours & 113 & $56.5 \%$ \\
\hline Total & $\mathbf{2 0 0}$ & $\mathbf{1 0 0 \%}$ \\
\hline
\end{tabular}

Source: Primary data

Figure 4

Working Hours

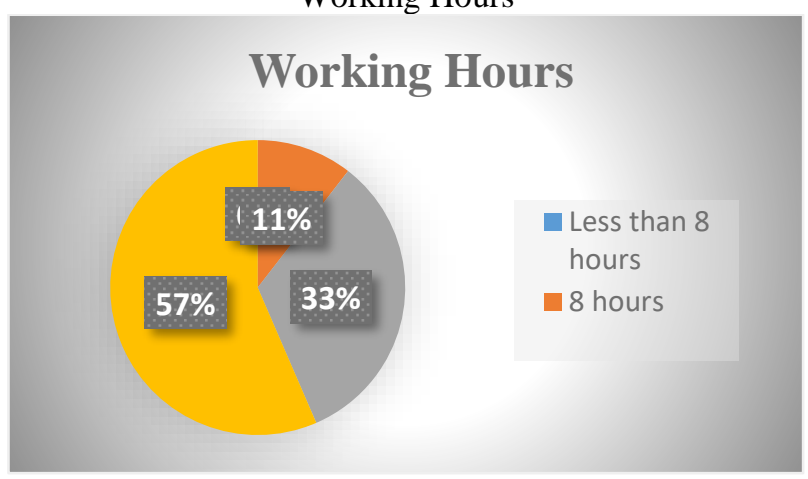

Table 2 
Most of the workers are working for more than 10 hours without any reluctance. This is the most Source: Primary data important factor which makes migrant labourers more attractive in kerala market.

Table 4

Satisfaction on quality of work

\begin{tabular}{|l|l|l|l|l|l|l|}
\hline Particulars & $\begin{array}{l}\text { Excellen } \\
\text { t }\end{array}$ & Good & $\begin{array}{l}\text { Satisfa } \\
\text { ctory }\end{array}$ & Bad & $\begin{array}{l}\text { Very } \\
\text { Bad }\end{array}$ & Percentage \\
\hline Wages related to the work done & 0 & 154 & 31 & 10 & 5 & $100 \%$ \\
\hline $\begin{array}{l}\text { Safe and secure working } \\
\text { environment }\end{array}$ & 18 & 45 & 97 & 26 & 14 & $100 \%$ \\
\hline Leave Facility & 0 & 11 & 107 & 68 & 14 & $100 \%$ \\
\hline Medical Facility & 8 & 69 & 95 & 18 & 10 & $100 \%$ \\
\hline Grievance Mechanism & 0 & 15 & 85 & 93 & 7 & $100 \%$ \\
\hline Support from local authority & 0 & 0 & 45 & 139 & 16 & $100 \%$ \\
\hline
\end{tabular}

Source: Primary data

Figure 5

Satisfaction on quality of work

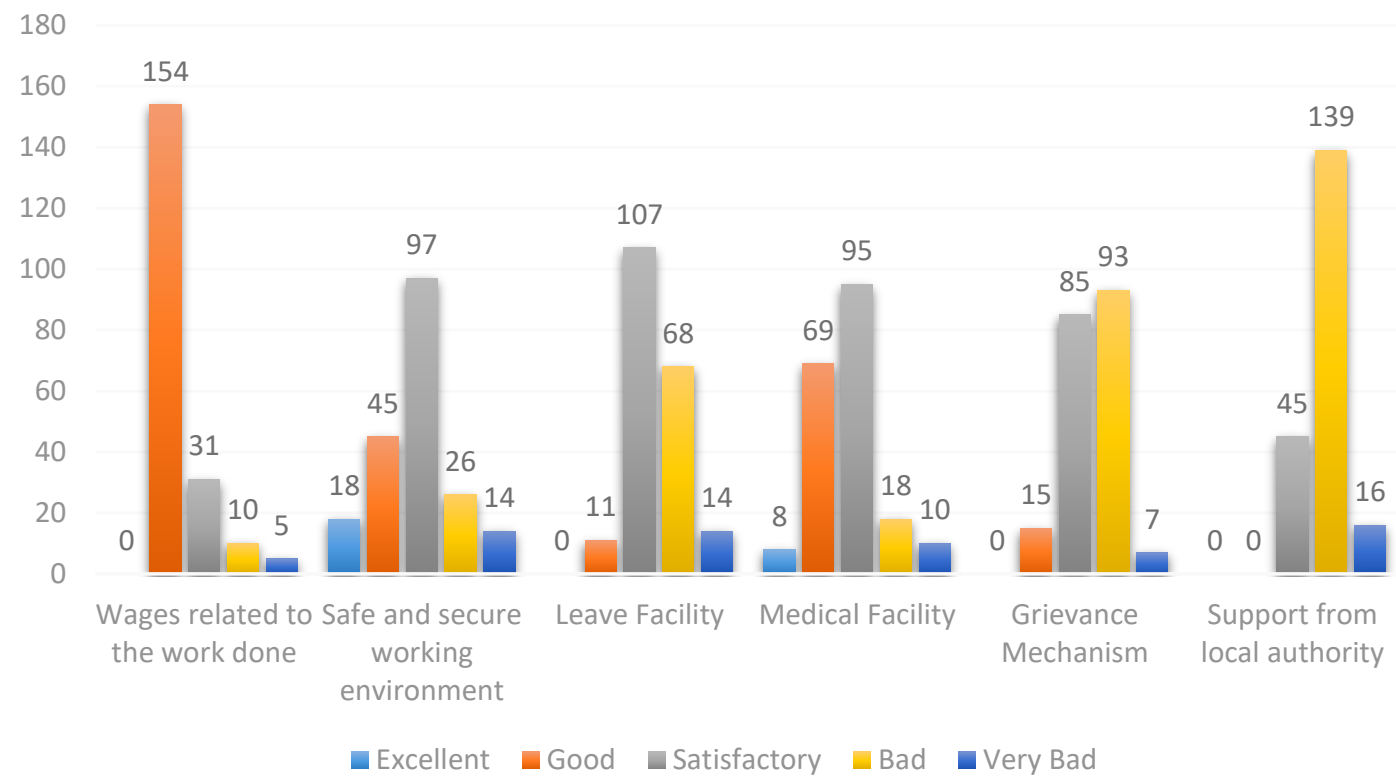

Source: Primary data

From the findings it can be concluded that majority of the respondents are satisfied by the working conditions provided in the state especially in case of wages and working environment. However, they often go for work even if they are sick, due to the fear of being replaced by another worker. They were also unhappy with the grievance mechanism. Majority of the respondents reported about the absence of proper medical facilities in the work place. It was often said that they had not been given any opportunity to speak up as the entire rules were dictated by the employers and the labour contractors.
Table 5

Awareness of Labour Laws

\begin{tabular}{|l|l|l|}
\hline Particulars & $\begin{array}{l}\text { Number of } \\
\text { Respondents }\end{array}$ & Percentage \\
\hline Yes & 14 & 7 \\
\hline No & 186 & 93 \\
\hline Total & $\mathbf{2 0 0}$ & $\mathbf{1 0 0} \%$ \\
\hline
\end{tabular}

Source: Primary data 
Awareness of Labour Laws

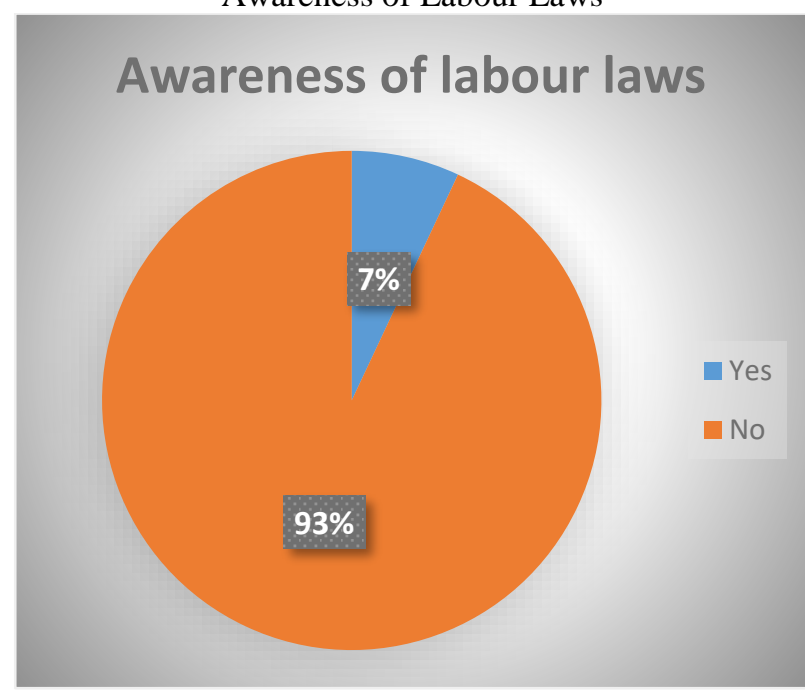

Source: Primary data

This is indeed a true fact that majority of the respondents had no idea regarding the labour laws prevailing in the state. This is taken as an advantage by many employers as these migrant labourers do not ask for more wages or for better working conditions.

\section{CONCLUSION}

The movement of people and increasing diversity of societies is one of the inevitable things in this world. Migration creates financial and social benefits for migrants, for their families and for the countries of origin and destination. Migrant labourers have become an increasingly important feature of modern economic life. It is important that we recognize the vital role that the migrants play in strengthening the global economy as well as helping to diversify the social fabric of our societies. Migration generates significant benefits in the state of Kerala too. Kerala is recently facing a lot of security threat due to the overflow of migrant labourers. This is an intimidating situation as majority of these labourers do not appear in any of the official records of the state.

The present study was conducted to know the reasons favoring the migrant unskilled labourers into the state. The research also analysed the working conditions available to these labourers in the state. The results of the study conclude that the employers were satisfied with the migrant unskilled labourers as they do not pose any problems such as increase in wages and working conditions to that of the local workers. It is understood that the migrant labourers are easy to manage, work continuously without breaks and have dedication to work.

The migrant labourers are also put in longer hours and they are ready to work overtime with no extra pay. It is very common especially in the construction sector that normal working day of these labourers extends to 14 hours a day. The migrant labourers are satisfied and content with their wages due to poor job market and extreme poverty in their home state. Because of the fact that agriculture has become uneconomical and lack of job opportunities in the industrial sector, these migrant labourers end up in Kerala seeking a job where they could earn more than the double they get in their homeland.

This study examined the multidimensional characteristics of migrant workers employed in Kerala from the other Indian states and portrayed the harsh realities and facts behind their migration. There areongoing changes in the country in all its dimensions and hence migration has also undergone apparent changes over the years. Migrant labourjs desirable and necessary to sustain economic and global growth. On the other hand, there is also a severe threat to security. Unless Kerala society and government address the issues effectively it is bound to throw up social problems and tensions of various kinds.

It is inevitable that the best way is to prepare well in advance to receive and accommodate such migrant labourers to lead a comfortable life in a hassle-free environment, so that they could be managed properly abiding all labour laws in the state. The authorities need to ensure that these migrant labourers enter the state with proper official records as in many cases it is observed that convicts of many cases in different states live and work here with no official records. The government should also make sure that these migrant labourers are provided with proper working conditions as well as better medical facilities.

\section{REFERENCES}

[1] Dr. Asha \& E Thomas.(2016). Labourmigration in kerala: A study on working conditions of unskilled labourers .International Journal of Engineering and Management Research, 6(10), 1-5.

[2] De Haans, A. \& Rogaly, B. (2002). Introduction: Migrant workers and their role in rural change. Journal of Development Studies, 37(5), 1-47.

[3] Joseph \& V. K. (2001). Factors and patterns of migration: The kerala experience. Journal of Indian School of Political Economy, 13(1), 55-72.

[4] Thomas \& Jayan Jose. (2012). India's labour market during the 2000s: Surveying the changes. Economic \& Political Weekly, 47(51), 39-51.

[5] Basu, \& A K. (2011). Impact of rural employment guarantee schemes on seasonal labour markets: Optimum compensation and workers. The Journal of Economic Inequality, 11(1), 1-34. 